\section{Water quality and pollution indices application in monitoring water quality of Serlui river impacted by Serlui-B dam, Mizoram, North East India}

\author{
Sangeeta Sunar*, Om Prakash Tripathi and

\section{B. P. Mishra}

Department of Environmental Science, Mizoram University, Aizawl 796 004, India

\begin{abstract}
The present study was carried out to determine the impact of the Serlui-B hydel project on water quality of Serlui river, Mizoram, North East India, using two popular mathematical indices, i.e. water quality index (WQI) and synthetic pollution index (SPI) and various water quality parameters. Three sampling sites were selected upstream and downstream of the river relative to the hydel project site. The computation of WQI and SPI indicates good quality of water at site 1 (upstream of the reservoir). In site 2 (in the reservoir) and site 3 (downstream of the reservoir) water quality got poorer because of the decrease in dissolved oxygen.
\end{abstract}

Keywords: Dissolved oxygen, hotspot region, hydel project, synthetic pollution index, water quality index.

IT has been reported that the construction of dams has resulted in fragmentation of $60 \%$ of the world's rivers ${ }^{1}$. An alteration in the river ecosystem induced by the dams results in disruption of the river channel and channel shrinkage $^{2}$, low water flow ${ }^{3}$, poor water quality of downstream/tail water ${ }^{4}$, decrease in the dissolved oxygen (DO) content and change in the thermal regime ${ }^{5}$, which lead to mobilization of the nutrients from the sediment and making it available for release in the downstream segment ${ }^{6}$. Submergence of large areas of land mass and vegetation in the reservoir are some of the other consequences of hydro-electric or irrigation projects. The decomposition of this large mass of submerged biomass triggers deoxygenation, increases nutrient loads and causes acidification of water ${ }^{7}$. In recent years water quality index (WQI) has emerged as one of the most effective tools to determine the quality and sustainability of water for human consumption, recreation, swimming, irrigation, fish swamping, etc. ${ }^{8-10}$. The equalized synthetic pollution index (SPI) involves mathematical models to determine the combined effect of various pollutants on the environment ${ }^{11}$. These indices reduce the complex datasets of various parameters to a single value in order to communi-

*For correspondence. (e-mail: Sangeetasunar90@gmail.com) cate information in a simplified and logical form to the citizens and policy makers ${ }^{12}$.

The Serlui (Rukni) river impounded by the Serlui-B dam $\left(24^{\circ} 20^{\prime} 18^{\prime \prime} \mathrm{N}\right.$ lat. and 92 46 $48^{\prime \prime} \mathrm{E}$ long.) located in the Kolasib district, Mizoram, North East India, is one of the major water sources with a length of about $55 \mathrm{~km}$ and width of $1.5 \mathrm{~km}$. From agriculture point of view, it is the single most important water system in the district with a large fluvial plain along its course providing for productive agricultural land. The total catchment area is $397 \mathrm{~km}^{2}$, with 21 villages in its vicinity ${ }^{13}$. Among those villages, Chemphai, Saphai and North Chawnpui with a total population of 7826 (ref. 14) are the major contributors to river pollution as they are settlements on the bank of the river. The inhabitants of these villages belong to the rural tribal community that is directly dependent on the river water for drinking and other domestic purposes, as there are no other proper facilities in the area. Agriculture is the main occupation of the villagers with about 868 ha under paddy cultivation. Agriculture is associated with improper application of chemical fertilizers like urea, SSP and $\mathrm{MOP}^{15}$. Around $22 \mathrm{~km}^{2}$ of forest land, including the Builum village, was completely submerged due to construction of the dam ${ }^{16}$. Earlier studies reveal that the construction of the Serlui-B dam has led to deterioration of the river water quality ${ }^{17,18}$ and reduction in species composition in the catchment area ${ }^{19}$. However, there is paucity of data to validate the water quality of Serlui river in term of drinking water. Therefore, the main objective of the present study was to determine the water quality for drinking purposes using two popular indices, namely WQI and SPI in view of the dependency of tribal inhabitants on this surface water for drinking without any treatment.

Water samples were collected from three sites: site $1-$ upstream of the reservoir where anthropogenic activities are the least, the river maintains its natural flow, and the sample from here is taken as reference site or control. Site 2 -reservoir and site 3 -downstream of the dam at the junction of the diversion outlet, spillover and power house along the river. Water samples were collected from these three sites at monthly intervals in replicates between March 2015 and February 2016, and the findings were recorded seasonally as pre-monsoon (PRM), monsoon (MON), post-monsoon (POM) and winter (WIN). For analysis of the various physico-chemical characteristics, standard methods were adopted ${ }^{20,21}$. A set of 12 most common water quality parameters, namely $\mathrm{pH}$, electrical conductivity (EC), DO, biological oxygen demand (BOD), total hardness (TH), total alkalinity (TA), total dissolved solids (TDS), total suspended solids (TSS), chloride $\left(\mathrm{Cl}^{-}\right)$, nitrate- $\mathrm{N}\left(\mathrm{NO}_{3}^{-}\right)$, phosphate-P $\left(\mathrm{PO}_{4}^{3-}\right)$ and sulphate $\left(\mathrm{SO}_{4}^{2-}\right)$, which together reflect the overall water quality status, were selected to develop WQI and SPI. The statistical analysis was done using SPSS 22 software package. 


\section{RESEARCH COMMUNICATIONS}

Table 1. Standard values, recommending scientific agencies and unit weight of selected water quality parameters

\begin{tabular}{lccc}
\hline Parameters & \multicolumn{1}{c}{$S_{n}$} & Recommending agencies for $S_{n}$ & Unit weight $\left(W_{n}\right)$ \\
\hline $\mathrm{pH}$ & $6.5-8.5$ & ICMR/BIS & 0.011 \\
Electrical conductivity (EC) & 300 & ICMR & 0.0003 \\
Dissolved oxygen (DO) & 5 & ICMR/BIS & 0.0188 \\
Biological oxygen demand (BOD) & 5 & ICMR & 0.0188 \\
Total hardness (TH) & 300 & ICMR/BIS & 0.0003 \\
Total alkalinity (TA) & 120 & ICMR & 0.0008 \\
Total dissolved solids (TDS) & 500 & ICMR/BIS & 0.0002 \\
Total suspended solids (TSS) & 500 & WHO & 0.0002 \\
$\mathrm{Cl}^{-}$ & 250 & ICMR & 0.0004 \\
$\mathrm{NO}_{3}^{-}$ & 10 & USPH & 0.0094 \\
$\mathrm{PO}_{4}^{3-}$ & 0.1 & USPH & 0.94 \\
$\mathrm{SO}_{4}^{2-}$ & 150 & ICMR/BIS & 0.0006 \\
\hline
\end{tabular}

ICMR, Indian Council of Medical Research; BIS, Bureau of Indian Standards; WHO, World Health Organisation; USPH, United States Public Health; $S_{\mathrm{n}}$, Standard permissible limit.

WQI was calculated using the arithmetic index method $^{22}$

$$
\mathrm{WQI}=\sum_{n=1}^{n} q_{n} W_{n} / \sum_{n=1}^{n} W_{n},
$$

where $q_{n}$ and $W_{n}$ are quality rating and unit weight of the $n$th water quality parameter respectively. Table 1 presents the standard values of recommending agencies and unit weight.

$$
\begin{aligned}
& q_{n}=\left[\left(V_{n}-V_{\mathrm{id}}\right) /\left(S_{n}-V_{\mathrm{id}}\right)\right] \times 100, \\
& W_{n}=k / S_{n},
\end{aligned}
$$

where $V_{n}, V_{\text {id }}$ and $S_{n}$ are the estimated value, ideal value (in most cases $V_{\text {id }}=0$, except for $\mathrm{pH}=7.0$ and $\mathrm{DO}=14.6)$ and standard permissible value of the $n$th water quality parameter respectively, and $k$ is the constant of proportionality.

$$
k=\left[1 /\left(\sum 1 / S_{n=1,2, . . n}\right] .\right.
$$

SPI was calculated using the following equation ${ }^{12}$

$$
\mathrm{SPI}=\sum_{n=1}^{n} \frac{C_{n}}{S_{n}} * W_{n}
$$

where $C_{n}$ and $S_{n}$ are the calculated and standard concentrations of the $n$th parameter respectively, and $W_{n}$ is the weight coefficient.

Table 2 presents the descriptive statistics of water quality parameter at selected sampling sites of Serlui river during PRM, MON, POM and WIN. The lowest values of $\mathrm{pH}$ and DO (6.2 and $5.9 \mathrm{mg}^{-1}$ respectively) were recorded at site 3 in MON while the highest $\left(7.6\right.$ and $7.6 \mathrm{mg}^{-1}$ respectively) at site 2 in WIN. The lowest values of EC, BOD, TDS, TSS, $\mathrm{NO}_{3}^{-}, \mathrm{PO}_{4}^{3-}$ and $\mathrm{SO}_{4}^{2-}\left(86 \mu \mathrm{S}, 0.6 \mathrm{mg} \mathrm{l}^{-1}\right.$,
$56 \mathrm{mg} \mathrm{l}^{-1}, \quad 23 \mathrm{mg} \mathrm{l}^{-1}, \quad 0.19 \mathrm{mg} \mathrm{l}^{-1}, \quad 0.024 \mathrm{mg} \mathrm{l}^{-1}$ and $1.8 \mathrm{mg} \mathrm{l}^{-1}$ respectively) were recorded at site 1 in WIN and the highest $\left(144 \mu \mathrm{S}, 2.0 \mathrm{mg} \mathrm{l}^{-1}, 264 \mathrm{mg} \mathrm{l}^{-1}, 75 \mathrm{mg} \mathrm{l}^{-1}\right.$, $0.51 \mathrm{mg} \mathrm{l}^{-1}, 0.157 \mathrm{mg} \mathrm{l}^{-1}$ and $5.8 \mathrm{mg} \mathrm{l}^{-1}$ respectively) at site 3 in MON. The lowest TH value $\left(44 \mathrm{mg} \mathrm{l}^{-1}\right)$ was recorded at site 1 in PRM and the highest $\left(228 \mathrm{mg} \mathrm{l}^{-1}\right)$ at site 3 in POM. The lowest TA value of $31.7 \mathrm{mg} \mathrm{l}^{-1}$ was recorded at site 1 in POM, and highest $\left(60.8 \mathrm{mg} \mathrm{l}^{-1}\right)$ at site 2 in MON. The lowest $\mathrm{Cl}^{-}$content $\left(34 \mathrm{mg} \mathrm{l}^{-1}\right)$ was recorded at site 1 in $\mathrm{MON}$, and highest $\left(132 \mathrm{mg} \mathrm{l}^{-1}\right)$ at site 3 in WIN during the study period. The result of the study reveals a marked increase in the abundance of pollutants (sediment load, accelerated run-off rate from agricultural land and discharge of excessive sewage from the riverside settlement) from site 1 to site 3 . A decrease in $\mathrm{pH}$ from upstream to downstream of the river indicates increasing acidity towards the downstream ${ }^{23}$. A sharp increase in the values of $\mathrm{EC}, \mathrm{BOD}, \mathrm{TA}, \mathrm{TH}, \mathrm{TDS}, \mathrm{Cl}^{-}$, $\mathrm{NO}_{3}^{-}, \mathrm{PO}_{4}^{3-}, \mathrm{SO}_{4}^{2-}$ and a marked decline in DO content from upstream to downstream of the river may be attributed to soil erosion, addition of waste through run-off (containing litter and domestic waste), and discharge of water after power generation from the powerhouse outlet directly into the river ${ }^{24,25}$. Increase in BOD content at site 2 (reservoir) may be the result of increased bacterial activity and decomposition of organic load as an outcome of submergence of large areas of productive forest due to the construction of the reservoir ${ }^{7,23}$, which is indicative of increased pollution stress due to the hydropower project. Higher values of TA at site 2 could also be attributed to washing of clothes in the reservoir (site 2) by the inhabitants residing in the vicinity. Similar trend has been reported by earlier workers in Mizoram ${ }^{23}$. Further, site 3 showed cumulative effects on water quality resulting in higher WQI values, and thereby a slightly more polluted status than site 2 . Higher value of suspended matter at site 3 may be attributed to topographical extremities (steep slopes, hilly terrain, etc.) and heavy rainfall in the $\operatorname{area}^{26}$. Agricultural practices prevailing in the catchment 
area add a new dimension to the enhancement of pollution load towards downstream of the $\mathrm{dam}^{27}$. The results reveal that all the parameters are within the prescribed limit of drinking water quality as given by various scientific agencies, except for phosphate $(\mathrm{P})$. Excess of $\mathrm{P}$ could be attributed due to agricultural run-off containing dissolved phosphatic fertilizers and sewage influx. Wastewater tends to increase $\mathrm{P}$ concentration in water ${ }^{28}$.

WQI is categorized into five classes $^{22}$ : grade A excellent (WQI value: 0-25); grade $\mathrm{B}$ - slightly polluted or good water (WQI value: $25-50$ ), grade $\mathrm{C}$ - moderately polluted or poor quality water (WQI value: $50-75$ ), grade $\mathrm{D}$ - polluted or very poor quality water (WQI value: 75 100), and grade E - extremely polluted or worst quality water (WQI value: $>100$ ). The WQI values ranged from 25 to 149 during the study period (Figure 1). The results revealed that water quality at site 1 (upstream of the reservoir) was grade A during WIN and grade B during PRM, MON and POM. Therefore, good quality of the water is indicated at site 1 . On the other hand, water quality at site 2 and site 3 was grades D and E during all sampling seasons. WQI analysis showed unsuitability of river water for drinking purposes at site 2. This may be attributed to the addition of nutrient-rich surface run-off from the nearby agricultural fields leading to eutrophication

Table 2. Descriptive statistics of water quality parameters (March 2015-February 2016)

\begin{tabular}{lccc}
\hline Parameters & Mean & Range & Standard error \\
\hline $\mathrm{pH}$ & 6.0 & 1.40 & 0.12439 \\
$\mathrm{EC}$ & 115.17 & 58 & 4.920 \\
$\mathrm{DO}$ & 6.9 & 1.7 & 0.1537 \\
$\mathrm{BOD}$ & 1.325 & 1.4 & 0.1156 \\
$\mathrm{TH}$ & 139.75 & 184 & 20.089 \\
$\mathrm{TA}$ & 45.017 & 29.1 & 2.9063 \\
$\mathrm{TDS}$ & 156.50 & 208 & 21.507 \\
$\mathrm{TSS}$ & 42.17 & 52 & 4.210 \\
$\mathrm{Cl}^{-}$ & 78.583 & 98.0 & 8.4741 \\
$\mathrm{NO}_{3}^{-}$ & 0.368 & 0.32 & 0.0347 \\
$\mathrm{PO}_{4}^{3-}$ & 0.09083 & 0.133 & 0.014339 \\
$\mathrm{SO}_{4}^{2-}$ & 3.892 & 4.0 & 0.3953 \\
$\mathrm{Water}^{--}$quality index (WQI) & 87.33 & 124 & 13.410 \\
\hline
\end{tabular}

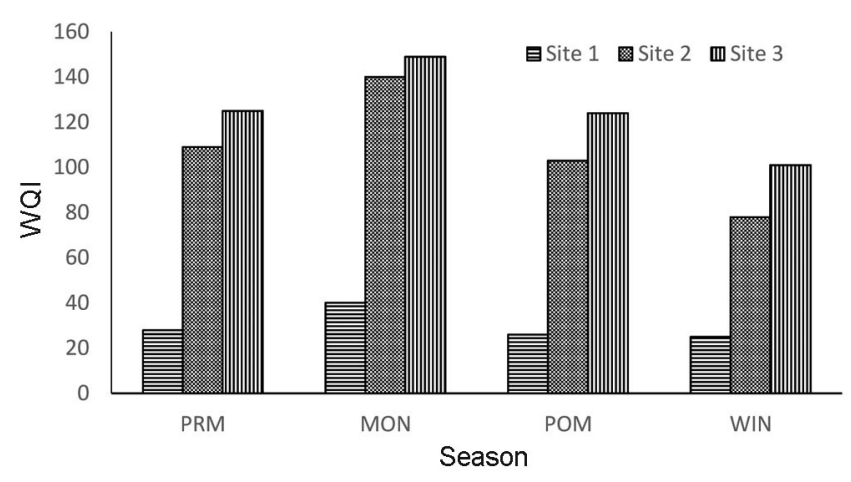

Figure 1. Water quality index of Serlui river at selected study sites. of the water body mainly due to conversion of the freeflowing river into a reservoir as a result of the dam construction. This causes stagnancy of the river due to scant flow $^{29}$, which in turn reduces the self-assimilation capacity of the river ecosystem ${ }^{30}$. Similarly, WQI values revealed a high degree of deterioration in the river water at site 3 , i.e. downstream of the dam, which could mainly be due to accelerated rate of soil erosion as an outcome of construction of the dam at site 2, socio-economic pressure and river-water exploitation for various purposes, and disposal of domestic sewage from the nearby settlements $^{31,32}$. Highest WQI values were recorded during MON (40 at site 1 to 149 at site 3) and lowest during WIN (25 at site 1 to 101 at site 3 ) in all the sampling sites. The deterioration of river water during MON is mainly attributed to removal of $22 \mathrm{~km}^{2}$ forest for dam construction and associated accelerated high rate of soil erosion due to increased run-off. Similar results have been reported by earlier researchers ${ }^{29,33}$.

From the correlation analysis it is evident that lower values of WQI at site 1 may be linked with higher DO content, as DO exhibits negative correlation with most of the parameters and WQI $(r=-0.997, P<0.001)$. It has already been reported that with increase in the values of other parameters, there is a significant decrease in the DO content ${ }^{18}$. Therefore, it can be considered as a useful measure for determining quality of water. At site 2, higher values of WQI are the result of higher values of water quality parameters like EC $(r=0.998, P<0.001)$, BOD $(r=0.940, P<0.001)$, TA $(r=0.828, P<0.005)$ and $\mathrm{PO}_{4}^{3-}$ $(r=0.998, P<0.001)$. Similarly, at site 3 , higher WQI values are related to higher values of EC $(r=0.904$, $P<0.001)$, BOD $(r=0.890, P<0.001)$, TA $(r=0.903$, $P<0.005), \mathrm{PO}_{4}^{3-}(r=1, P<0.001)$ and $\mathrm{SO}_{4}^{2-}(r=0.834$, $P<0.001)$. There exists a strong positive and significant correlation between WQI and the above-mentioned water quality parameters. Regression study (Table 3 ) shows that the high WQI value may be linked with increase in EC, BOD, TDS, TH, $\mathrm{Cl}^{-}, \mathrm{NO}_{3}^{-}, \mathrm{PO}_{4}^{3-}$ and $\mathrm{SO}_{4}^{2-}$, and a decrease in the DO content in the water downstream. The loadings of all physico-chemical parameters having eigenvector values greater than 1 were characterized statistically using principal component analysis $(\mathrm{PCA})^{34}$. Table 4 describes the contribution of each variable to the components. The first two components altogether describe $83 \%$ of the total variance. The first component contributes $68 \%$ of the total variance and represents significant strong loading of EC, BOD, TDS, $\mathrm{NO}_{3}^{-}, \mathrm{PO}_{4}^{3-}$ and $\mathrm{SO}_{4}^{2-}$ indicating that organic pollutants are the major source of pollution in Serlui river. This may be attributed to dam construction leading to soil erosion and influx of fertilizers from the nearby agricultural fields into the river. A negative loading of $\mathrm{pH}$ and $\mathrm{DO}$ is attributed to decomposition of organic matter ${ }^{35}$. The second component with $15 \%$ total variance is largely a function of $\mathrm{TH}$ and $\mathrm{Cl}^{-}$, which may be attributed to anthropogenic activities. 
Table 3. Regression study of WQI at selected study sites

\begin{tabular}{|c|c|c|c|c|c|c|}
\hline \multirow[b]{2}{*}{ Pairs of parameters } & \multicolumn{2}{|l|}{ Site 1} & \multicolumn{2}{|l|}{ Site 2} & \multicolumn{2}{|l|}{ Site 3} \\
\hline & Regression equation & $r^{2}$ & Regression equation & $r^{2}$ & Regression equation & $r^{2}$ \\
\hline WQI-pH & $y=-20.914 x+177.95$ & 0.86 & $y=-42.222 x+406.22$ & 0.56 & $y=-80.556 x+644.33$ & 0.51 \\
\hline WQI-EC & $y=0.2424 x+3.5596$ & 0.44 & $y=1.6543 x-78.198$ & 1.00 & $y=1.0987 x-12.59$ & 0.82 \\
\hline WQI-DO & $y=-14.602 x+133.75$ & 1.00 & $y=-47.138 x+443.36$ & 0.81 & $y=-37.444 x+366.27$ & 0.55 \\
\hline WQI-BOD & $y=12.181 x+15.708$ & 0.38 & $y=62.011 x+34.637$ & 0.88 & $y=51.067 x+39.213$ & 0.42 \\
\hline WQI-TH & $y=0.2558 x+15.27$ & 0.11 & $y=0.1572 x+80.228$ & 0.06 & $y=0.2216 x+82.817$ & 0.25 \\
\hline WQI-TDS & $y=0.4082 x-0.7868$ & 0.67 & $y=0.2651 x+61.767$ & 0.35 & $y=0.1884 x+82.88$ & 0.18 \\
\hline WQI-TSS & $y=0.3612 x+17.501$ & 0.37 & $y=0.6732 x+78.891$ & 0.06 & $y=0.4931 x+100.09$ & 0.25 \\
\hline WQI-Cl- & $y=-0.3641 x+47.064$ & 0.56 & $y=-1.1196 x+208.8$ & 0.85 & $y=-0.7451 x+197.38$ & 0.78 \\
\hline WQI-NO ${ }_{3}^{-}$ & $y=60.27 x+14.348$ & 0.14 & $y=130.79 x+58.455$ & 0.39 & $y=219.01 x+21.27$ & 0.59 \\
\hline WQI-PO ${ }_{4}^{3-}$ & $y=939.4 x+2.09$ & 1.00 & $y=940.14 x+1.7347$ & 1.00 & $y=923.12 x+4.0521$ & 1.00 \\
\hline WQI-SO ${ }_{4}^{2-}$ & $y=7.4017 x+9.7059$ & 0.55 & $y=16.266 x+44.062$ & 0.63 & $y=14.576 x+51.143$ & 0.69 \\
\hline
\end{tabular}

Table 4. Factor analysis, total variance and matrix of factor loading for water quality of Serlui river

\begin{tabular}{|c|c|c|c|c|c|c|}
\hline \multirow[b]{2}{*}{ Components } & \multirow[b]{2}{*}{ Total } & \multicolumn{3}{|c|}{ Initial eigenvalues } & \multicolumn{2}{|c|}{ Matrix of factor loading } \\
\hline & & Percentage of variance & Cumulative (\%) & Parameters & PCA 1 & PCA 2 \\
\hline 1 & 8.115 & 67.625 & 67.625 & $\mathrm{pH}$ & -0.886 & 0.239 \\
\hline 2 & 1.802 & 15.014 & 82.638 & $\mathrm{EC}$ & 0.814 & -0.450 \\
\hline 3 & 0.813 & 6.772 & 89.410 & DO & -0.849 & 0.340 \\
\hline 4 & 0.493 & 4.112 & 93.523 & BOD & 0.872 & -0.298 \\
\hline 5 & 0.369 & 3.078 & 96.600 & $\mathrm{TH}$ & 0.852 & 0.474 \\
\hline 6 & 0.259 & 2.161 & 98.761 & TA & 0.668 & -0.151 \\
\hline 7 & 0.088 & 0.733 & 99.494 & TDS & 0.929 & 0.320 \\
\hline 8 & 0.040 & 0.336 & 99.831 & TSS & 0.774 & -0.106 \\
\hline 9 & 0.012 & 0.100 & 99.931 & $\mathrm{Cl}^{-}$ & 0.268 & 0.913 \\
\hline 10 & 0.007 & 0.060 & 99.991 & $\mathrm{NO}_{3}^{-}$ & 0.927 & 0.103 \\
\hline 11 & 0.001 & 0.009 & 100 & $\mathrm{PO}_{4}^{3-}$ & 0.868 & 0.361 \\
\hline 12 & $-1.821 \mathrm{E}-16$ & $-1.517 \mathrm{E}-15$ & 100 & $\mathrm{SO}_{4}^{2-}$ & 0.933 & -0.050 \\
\hline
\end{tabular}

Extraction method, Principal component analysis (PCA).

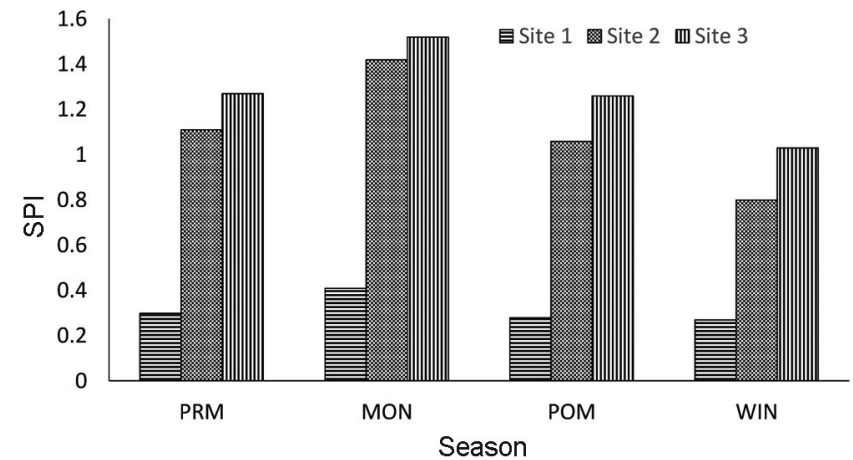

Figure 2. Synthetic pollution index of Serlui river at selected study sites

The water quality is classified into five categories based on $\mathrm{SPI}^{12}$, i.e. suitable (SPI $\left.<0.2\right)$, slightly polluted (SPI 0.2-0.5), moderately polluted (SPI 0.5-1), highly polluted (SPI 1-3) and unsuitable for drinking (SPI > 3). The SPI values ranged from 0.27 at site 1 during WIN to 1.52 at site 2 during MON (Figure 2). The results revealed that water quality was between 0.2 and $0.5 \mathrm{SPI}$ at site 1 , which indicates suitability of water for domestic purposes, although not for drinking. An increase in SPI value at site 2 and site 3 (values ranging between 1 and 3 ) indicates higher pollution load in the reservoir and downstream of the dam. Seasonally, lower SPI value was observed during WIN and higher values during MON at all three sites.

WQI and SPI indices were used to determine the water quality status of Serlui river in terms of potability in the selected study area as the local inhabitants utilize the river water directly for drinking without any treatment. Comparison of WQI and SPI indices of the control, reservoir and dam site samples showed marked impact of the upcoming hydro-electric power project on water quality. The results of these indices reveal that water quality downstream of the dam is such that it is not suitable for drinking purpose without treatment. This is largely associated with increase in anthropogenic activities leading to increase in pollutants in the catchment area of the reservoir. The rapid deterioration of water quality during the monsoon season may be the consequence of construction of the dam as the soil in the catchment area is left bare and thereby more prone to erosion. Based on WQI and 


\section{RESEARCH COMMUNICATIONS}

SPI, it can be concluded that the Serlui river exhibits poor water quality at site 2 and site 3 compared to site 1, indicating negative impact of the Serlui-B hydroelectric power project on water quality. Thus treatment of water is recommended before it is used for drinking as well as for domestic purposes, because long-term use of such untreated water may lead to adverse health effects.

1. Alobeidy, A., Abid, H. S. and Maulood, B. K., Assessment of water quality index for assessment of Dokan lake ecosystem, Kurdistan region. Iran J. Water Resour. Prot., 2011, 2, 792-798.

2. Hydraulic Institute of Yellow River Conservancy Committee. Collected Papers of Scientific Research, China Environmental Science Press, 1993.

3. Hassan, S. S., Sinha, R. K., Hassan, N. and Ahsan, I., The current seasonal variation incatch diversity and composition of fish communities vis-à-vis various factors in the Ganges at Patna (India) and strategies for sustainable development. Freshwater Biol., 1998, 10, 141-157.

4. Kennedy, R. H. and Gaugush, R. F., Assessment of water quality in corps of engineers reservoirs. Lake Resour. Manage., 1988, 4, 253-260.

5. Ward, J. V. and Stanford, J. A., The ecology of regulated streams: past accomplishments and directions for future research. In Regulated Streams Advances in Ecology (eds Craig, J. F. and Kemper, J. B.), Plenum Press, New York, USA, 1987, pp. 391-409.

6. Ashby, S., Impacts of hydrology and hydropower on water quality in reservoir tailwaters. River Basin Manage., 2009, 55, 55-66.

7. Sharma, D. K., Impacts of dams on river water quality. Int J. Curr. Adv. Res., 2015, 4, 176-181.

8. Tiwari, T. N. and Mishra, M. A., A preliminary assignment of water quality index of major Indian rivers. Indian J. Environ. Prot., 1985, 5, 276-279.

9. Tyagi, S., Sharma, B., Singh, P. and Dobhal, R., Water quality assessment in terms of water quality index. Am. J. Water Resour., 2013, 1, 34-38

10. Ewaid, S. H. and Abed, S. A., Water quality index for Al-Gharraf River, southern Iraq. Egypt. J. Aquat. Res., 2017, 43, 117-122.

11. Xiao, C., Application of the equalized synthetic pollution index method to the assessment of groundwater quality pollution in the former Guoguan district, Jilin. Water Conserv., 1996, 11, 33-35.

12. Solangi, G. S., Siyal, A. A., Babar, M. M. and Siyal, P., Groundwater quality evaluation using the water quality index (WQI), the synthetic pollution index (SPI), and geospatial tools: a case study of Sujawal district, Pakistan. Hum. Ecol. Risk Assess., 2019; https://doi.org/10.1080/10807039.2019.1588099.

13. Department of Public Health Engineering, Kolasib, Mizoram, 2012.

14. Census, Register General of India, Ministry of Home affair, Government of India, 2011

15. Comprehensive District Agricultural Plan for Rashtriya Krishi Vikas Yojana of XI Five-year plan, District Agriculture Department, Kolasib, Mizoram, 2012.

16. Mizoram Remote Sensing Application Centre, Government of Aizwal, Mizoram, 2016

17. Sunar, S. and Mishra, B. P., Assessing the impact of hydroelectric power project on the water quality of Serlui River in Kolasib district, Mizoram, North-East India. Int. Res. J. Environ. Sci., $2016,5,40-44$.

18. Sunar, S. and Mishra, B. P., Correlation and linear regression as a water quality monitoring tool for Serlui river in Kolasib district, Mizoram, India. Int. Res. J. Academic Res. Dev., 2018, 3, 676680
19. Mishra, B. P. and Sunar, S., Developmental activities in relation to change in diversity-distribution of medicinally important plants in vicinity of Serlui-B hydel project, Mizoram, India. Indian For., 2019, 21, 1157-1165.

20. APHA, Standard Methods for the Examination of Water and Waste Water, American Public Health Association, American Water Works Association and Water Environment Federation, Washington, DC, USA, 2005, 21st edn.

21. Maiti, S. K., Handbook of Methods in Environment Studies, Water and Waste Water Analysis, Oxford, UK, 2001, vol. 1, pp. 138141.

22. Brown, R. M., McClelland, N. I., Deininger, R. A. and O'Connor, M. F., Water quality index - crashing the physicological barrier. Proc. 6th Annual Conference. Adv. Water Pollut. Res., 1972, 6, 787-794.

23. Lalparmawii, S. and Mishra, B. P., Seasonal variation in water quality of Tuirial river in vicinity of the hydel project in Mizoram. Sci. Vis., 2012, 12, 159-163.

24. Mishra, B. P. and Tripathi, B. D., Impact of city sewage discharge in physico-chemical characteristics of river Ganga water. Asian $J$. Microbiol. Biotechnol. Environ. Sci., 2001, 3, 333-338.

25. Mishra, B. P. and Tripathi, B. D., Seasonal variation in physicochemical characteristics of Ganga River as influenced by sewage discharge. Indian J. Ecol., 2003, 30, 27-32.

26. Pachuau, R., Geography of Mizoram, R.T. Enterprise, Mizoram, India, 1994, pp. 153

27. Pawar, R. M. and Shendge, N. M., Analysis of physico-chemical properties of water from different sources in and around Pune city. Asian J. Multidiscip. Stud., 2016, 4, 110-115.

28. Rizvi, N., Katyal, D. and Joshi, V., Assessment of water quality of Hindron River in Ghaziabad and Noida, India by using multivariate statistical methods. J. Global Ecol. Environ., 2015, 3, 8090.

29. Lkr, A., Singh, M. R. and Puro, N., Assessment of water quality status of Doyang river, Nagaland, India using water quality index. Appl. Water Sci., 2020, 10, 1-13.

30. Sharma, D. K., Impacts of dams on river water quality. Int. J. Curr. Adv. Res., 2015, 4, 176-181.

31. Bouslah, S., Djemili, L. and Houichi, L., Water quality index assessment of Koudiat Medouar Reservoir, northeast Algeria using arithmetic index method. J. Water Land Dev., 2017.

32. Shah, K. A. and Joshi, G. S., Evaluation of water quality index for River Sabarmati, Gujarat. Appl. Water Sci., 2017; https://doi.org/ 10.1515/jwld-2017-0087

33. Bora, M. and Goswami, D. C., Water quality assessment in terms of water quality index (WQI): case study of the Kolong River. Appl. Water Sci., 2017.

34. Shrestha, S. and Kazama, F., Assessment of surface water quality using multivariate statistical techniques: a case study of the Fuji river basin, Japan. Environ. Modell. Softw., 2007, 22, 464-475.

35. Ling, T.-Y., Soo, C.-L., Liew, J.-J., Nyanti, L., Sim, S.-F. and Grinang, J., Application of multivariate statistical analysis in evaluation of water quality of a tropical river. J. Chem., 2017, $1-13$.

ACKNOWLEDGEMENT. We thank to Mizoram University, Aizawl for infrastructural facilities and officials of the Serlui-B dam for support during the field study.

Received 17 May 2020; revised accepted 26 August 2020

doi: $10.18520 / \mathrm{cs} / \mathrm{v} 119 / \mathrm{i} 10 / 1685-1689$ 